\title{
Vitenskapelig usikkerhet - etiske utfordringer for forskning og forvaltning
}

\author{
Froydis Gillund og Anne Ingeborg Myhr
}

En stor del av dagens forskningsaktivitet er knyttet til utvikling av ny teknologi. Teknologiutvikling anses gjerne som et gode, fordi den bidrar til økt eller ny bruk av naturlige ressurser til beste for menneskers generelle levekår og helse, samt miljøet og samfunnet som helhet. Bruk av ny teknologi inneborer imidlertid også risiko for uønskede effekter. Risikovurderinger er ofte preget av vitenskapelig usikkerhet, spesielt med hensyn til effekter som oppstår over tid. Denne usikkerheten reiser nye etiske dilemmaer og gjør det nødvendig med en kritisk vurdering av kunnskapsgrunnlaget. I denne artikkelen fokuserer vi på hvilke etiske utfordringer vitenskapelig usikkerhet har for forskning og forvaltning, og vi vil se noermere på bruk av DNA-vaksiner i oppdrettsnoring. Vi argumenterer for at det er viktig å anerkjenne kvalitative former for vitenskapelig usikkerhet, som går utover det som uttrykkes i statistiske termer. Walker \& Harremoës (WઐH) usikkerhetsanalyse presenteres som en metode for å identifisere og systematisere vitenskapelig usikkerhet av kvalitativ karakter. En slik analyse kan øke forskeres evne til å reflektere over og kommunisere usikkerhet knyttet til eget arbeid. Vi argumenterer videre for at kommunikasjon av vitenskapelig usikkerhet bør vore en del av forskerens etiske ansvar, blant annet for å stimulere føre-var-basert forskning og forvaltning. En helhetsvurdering av nytte, risikomomenter og usikkerhet kan best oppnås gjennom en tverrfaglig tilnoerming. Det vil bidra til at de implisitte verdiene som er assosiert til bruk av ny teknologi blir bedre belyst.

Nøkkelord: vitenskapelig usikkerhet, DNA-vaksine, føre-var-prinsippet, risikovurdering, usikkerhetsanalyse, tverrfaglighet. 


\section{Innledning}

Forskning kan beskrives som en kontinuerlig kunnskapsutvikling hvor målet er å frembringe stadig bedre beskrivelser av verden og hvordan den fungerer (Hines 2001). Fra den moderne vitenskapens opprinnelse på 1600-tallet har blant annet sikkerhet, objektivitet og verdinøytralitet vært idealer for vitenskapelig praksis og kunnskap. Usikkerhet ble oppfattet som en midlertidig tilstand som lot seg redusere gjennom mer forskning, gjerne i form av idealiserte laboriatorieeksperimenter av enkeltkomponentene i systemet. Statistikken ble utviklet som en metode for å få kontroll over usikkerhet knyttet til vitenskapelige resultater.

I den senere tid har imidlertid usikkerhet i større grad blitt oppfattet som en iboende del av vitenskapen og av de naturlige og sosiale systemene som den forsøker å beskrive. Noe av årsaken til denne erkjennelsen har sin opprinnelse i nyere tids dramatiske konsekvenser ved bruk av ny teknologi (f.eks. Tjernobyl-ulykken, kugalskapskandalen og drivhuseffekten), samt forskeres manglende evne til å forutse og vurdere hvordan disse konsekvensene best bør håndteres (Harremoës et al. 2001). Det har bidratt til en økt forståelse av at natur og samfunn er komplekse systemer, hvor kompleksiteten er av en slik art at vitenskapen kan komme til kort i sin beskrivelse og forståelse av den. Det blir dermed svært relevant å se på det som ligger til grunn for vitenskapelig kunnskapsutvikling, samt hvordan vitenskapelig usikkerhet kommuniseres og håndteres i forskning og forvaltning.

Utvikling av DNA-vaksiner er et godt eksempel på at tiden fra vitenskapelig forskning til teknologisk bruk blir stadig kortere. Videre representerer bruk av DNA-vaksiner i human og veterinær medisin endringer i et komplekst økologisk system, endringer som kan være umulig å forutse. Til tross for mulighetene denne teknologien representerer, i form av bedre bekjempelse av sykdomsfremkallende organismer, er det fremdeles lite kunnskap omkring DNA-vaksiners økologiske, økonomiske og øvrige etiske implikasjoner. I dag aksepterer vi ofte en viss risiko for uønskede effekter hvis vi har opplagt nytte ved bruk av teknologien. Utfordringen er å veie nytte og kostnader, samt å inkludere nytte eller kostnader som først inntrer over tid i vurderingen. Forskere spiller en stadig mer sentral rolle i denne sammenhengen, for eksempel som eksperter og rådgivere i risikovurderinger og $\mathrm{i}$ politiske beslutninger, noe som øker behovet for utvidede etiske retningslinjer for forskningspraksis.

Denne artikkelen omhandler kunnskapsutvikling og hvilke utfordringer vitenskapelig usikkerhet har for forskning og forvaltning. Samfunnet trenger informasjon om teknologiprodukters kvaliteter, og indikasjoner på hva som kan gå galt dersom de tas i bruk. Videre må sikkerhet og gyldighetsområde for forskningsresultatene kommuniseres. Dette stiller naturvitenskapene overfor nye utfordringer, hvor etisk refleksjon over forutsetninger for forskningen og kommunikasjon av kunnskapens kvalitet er viktige aspek- 
ter. Vi foreslår et verktøy, Walker \& Harremoeës (W\&H) usikkerhetsanalyse (Walker et al. 2003), som kan brukes til å kartlegge usikkerhet og indikere behov for videre forskning. Anerkjennelse av kvalitativ usikkerhet innebærer at forskeransvaret går utover tradisjonelle forskningsetiske standarder. Videre er vurdering av hva som er et alvorlig miljøproblem, fornuftige tiltak og hvordan man bør forske på dem, avhengig av verdisyn og etiske preferanser. For å møte de faglige utfordringene som usikkerhet og kompleksitet representerer ved vurderinger av mulige helse og miljøeffekter og deres etiske implikasjoner, argumenterer vi for en tverrfaglig tilnærming til problemet.

\section{DNA-vaksinasjon i fiskeoppdrett}

Økende etterspørsel etter fisk og sjødyr har ført til stor ekspansjon i oppdrettsnæringen globalt. I Norge er spesielt produksjon av oppdrettslaks i sterk vekst. Beregninger fra Statistisk sentralbyrå (2007) viser at det totalt ble det solgt litt over 626000 tonn norsk oppdrettslaks i 2006, noe som er en økning på 7 prosent fra året før. Fiskesykdommer og begrenset tilgang på fôrressurser av god kvalitet setter imidlertid grenser for fremtidig vekst i norsk oppdrettsnæring. Bruk av genteknologi til utvikling av blant annet transgen fisk, genmodifiserte (GM) planter til fôr eller spiselige vaksiner, og DNA-vaksiner kan være teknologiske løsninger på disse utfordringene.

Det er estimert at sykdomsfremkallende organismer (patogener), som bakterier, parasitter og virus, fører til 10 prosent reduksjon i produksjon av oppdrettsfisk (Leong \& Fryer 1993). Forskere har ikke lykkes med å utvikle tradisjonelle vaksiner for å kontrollere flere av disse patogenene. DNA-vaksiner, derimot, har vist seg å være effektive, spesielt for bekjempelse av virussykdommer. Så langt er kun én DNA-vaksine - IHNV DNA-vaksine som beskytter mot infeksiøs hematopoietisk nekrose virus hos atlantisk laks - tillatt for kommersielt bruk i Canada (Novartis 2005).

\section{DNA-vaksine}

En DNA-vaksine består av sirkulære DNA-kjeder (plasmider). Disse har fått tilført et gen som koder for produksjon av proteinantigen mot et spesifikt patogen når plasmidet injiseres i fiskens muskelceller. For at produksjonen av proteinantigen skal finne sted, må DNA-plasmidet komme inn i cellekjernen, hvor proteinantigenet produseres ved hjelp av cellens egen proteinsyntese og transporteres til cellens overflate. Immunapparatet gjenkjenner disse cellene, og immunsystemet aktiveres. På denne måten blir fisken beskyttet mot fremtidig angrep fra patogenet. DNA-vaksiner er attraktive fordi de blant annet er billige og enkle å produsere, de er stabile 
ved ulike temperaturer, og de gir muligheter for å utvikle en vaksine som beskytter mot flere ulike patogener (Hew \& Fletcher 2002). Videre fører bruk av DNA-vaksiner til at man unngår deformiteter og skader på fiskens organ, noe som kan forekomme ved bruk av tradisjonelle oljebaserte adjuvansvaksiner (Bergh et al. 2006).

\section{Vitenskapelig usikkerhet knyttet til bruk av DNA-vaksiner}

Det er imidlertid gjort få vitenskapelige studier av økologiske, økonomiske og øvrige etiske implikasjoner ved bruk av DNA-vaksiner i oppdrettsnæringen. I forhold til økologiske og biologiske aspekter ved bruk av DNAvaksiner er det usikkerhet både omkring immunologiske responser etter vaksinering og hva som skjer med DNA-plasmidet etter injisering i fiskens celler, samt effekter ved eventuell utslipp til det akvatiske miljø (Myhr \& Dalmo 2005) (se figur 1). Dette virker inn på krav om dyrevelferd og produktmerking, samt konsumentaksept og markedspris.

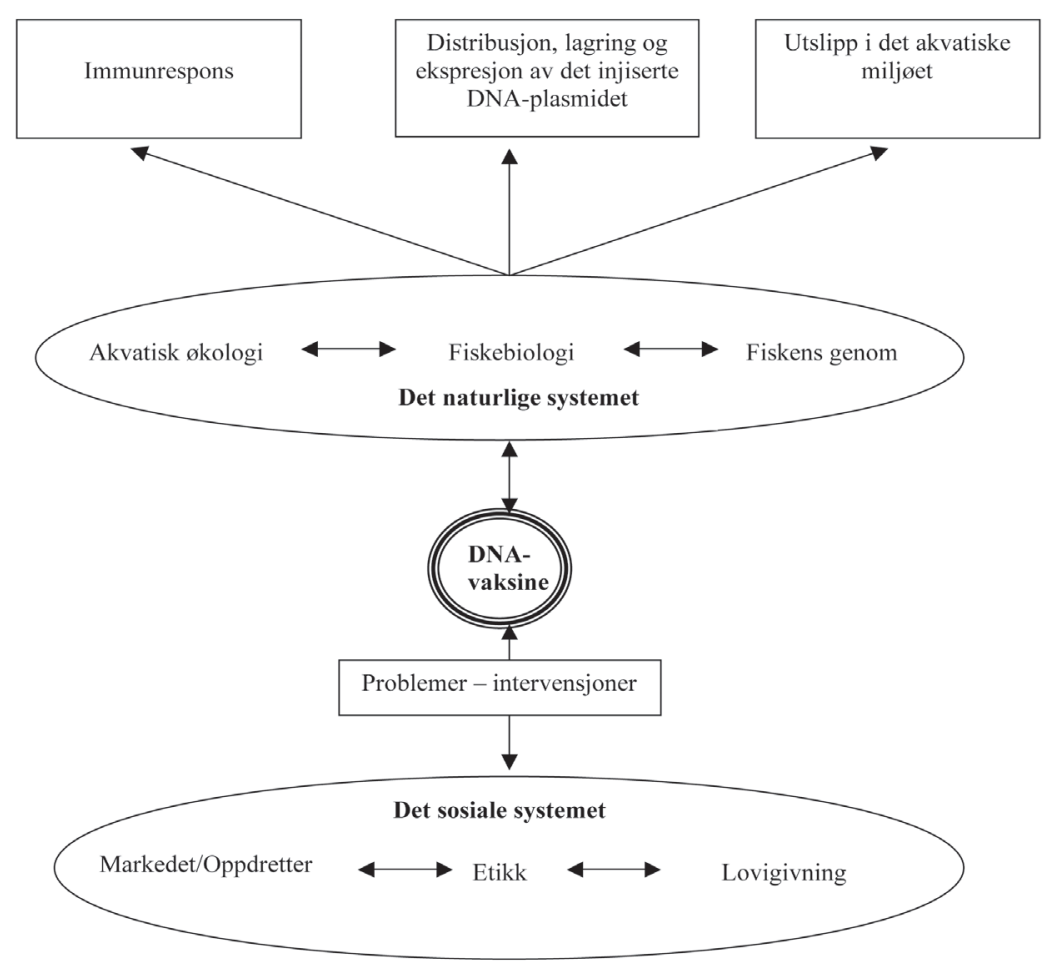

Figur 1 Økologiske, økonomiske og øvrige etiske implikasjoner ved bruk av DNA-vaksine 
I tillegg til den forventede beskyttelsen mot en bestemt sykdomsfremkallende organisme, kan DNA-vaksinasjonen også føre til en rekke immunresponser som i utgangspunktet ikke var forutsett. Det inkluderer responser som øker fiskens resistens mot sykdomsfremkallende organismer, for eksempel en generell stimulering av immunsystemet eller kryssbeskyttelse, slik at fisken blir resistent mot flere ulike patogener (Lorenzen et al. 2002). Skadelige immunresponser kan imidlertid også forekomme. Eksempler på dette er at fiskens immunsystem angriper egne celler (autoimmunitet) (Klinman et al. 1996), eller at fisken utvikler toleranse mot vaksinen, slik at immunsystemet ikke aktiveres (Mor et al. 1996). Videre kan inflammasjonsreaksjonen som induseres av vaksinen, skade eller ødelegge celler og organer.

Få studier har tatt sikte på å undersøke stabilitet, distribusjon og ekspresjon av DNA-plasmidet etter injeksjon i fiskens muskelceller. Avhengig av blant annet mengde og type vaksine, samt injeksjonssted, vil vaksinen kunne transporteres til andre organer enn injeksjonsstedet, og lagres og eventuelt uttrykkes der (Tonheim et al. 2007). Spesielt aktuelt er muligheten for at gener fra DNA-plasmidet integreres i fiskens genom. Dersom integreringen skjer i fiskens gondale kromosom, vil endringene kunne overføres til fiskens avkom. Videre er det knyttet usikkerhet til mulighetene for utslipp til miljøet for eksempel via fiskens avføring, eller ved at fisk dør og brytes ned eller rømmer fra merdene. Søling av vaksine under vaksinering er også en kilde til utslipp. DNA er mer resistent mot nedbryting i økosystemet (inkludert det akvatiske økosystemet) og etter opptak i mikroorganismer enn tidligere antatt (Heinemann \& Roughan 2000). Lite er kjent i forhold til mulighet for og frekvens av opptak av DNA-plasmid i andre organismer i det akvatiske miljøet og effekten av dette. Det inkluderer også konsekvenser for mennesker som spiser DNA-vaksinert fisk.

En rekke forhold er relevante for å vurdere de sosioøkonomiske og de øvrige etiske aspektene ved introduksjon av DNA-vaksine. Økonomisk lønnsomhet er en betingelse for at vaksinen tas i bruk. I tillegg til at en bedret beskyttelse mot patogener vil kunne gi økt avkastning, vil det også kunne bedre fiskevelferden. Så lenge det er usikkerhet om hvorvidt DNAplasmidet kan integreres i fiskens kromosom, mener norske myndigheter at DNA-vaksinert fisk skal merkes som en genmodifisert organisme (GMO) (Direktoratet for naturforvaltning 2001), og det vil sannsynligvis virke inn på konsumentaksept og markedspris.

\section{Utfordringer ved et komplekst natursyn}

Ifølge Prigogine (1980) kan man velge å se på naturen som enten enkel, komplisert eller kompleks. Ved å velge å behandle naturen som et enkelt 
system opererer man med en kort tidshorisont, likevektssammenhenger og reversibilitet. Videre antas det at konsekvensene av en handling er enkle å forutse, og at det er mulig å beregne sannsynligheten for at de skal inntreffe. I en komplisert naturoppfatning er forholdet mellom handling og effekt mindre entydig, og sannsynligheten for et gitt utfall er sjelden opplagt. Kompleksitet er karakterisert av en enda større grad av uforutsigbarhet. Komplekse systemer kan beskrives på flere måter (Cilliers 2005), med interaksjoner og tilbakevirkningsmekanismer på ulike nivå. Man opererer oftest med et langt tidsperspektiv (Chu et al. 2003) og erkjenner at handlinger kan ha irreversible konsekvenser.

Beskrivelsen av mulige implikasjoner ved bruk av DNA-vaksine i oppdrettsnæringen viser at vaksinering handler om mye mer enn direkte forventet immunrespons. Bildet blir ytterligere komplisert av eventuelle uønskede langtidsvirkninger og muligheten for å forutse disse. Det at det finnes flere beskrivelser for komplekse systemer, og at årsak-virkning-forholdene kan være vanskelig å definere, gjør at vitenskapelig usikkerhet blir svært relevant.

\section{Vitenskapelig usikkerhet}

Det finnes ulike kategoriseringer av vitenskapelig usikkerhet (se f.eks. Stirling 2001; Wynne 1992; Walker et al. 2003). Til tross for noe ulik begrepsbruk, karakteriseres usikkerhet som en gradvis endring fra deterministisk kunnskap, hvor alt er kjent, til total ignoranse, hvor en ikke engang vet hva en ikke vet (se figur 2).

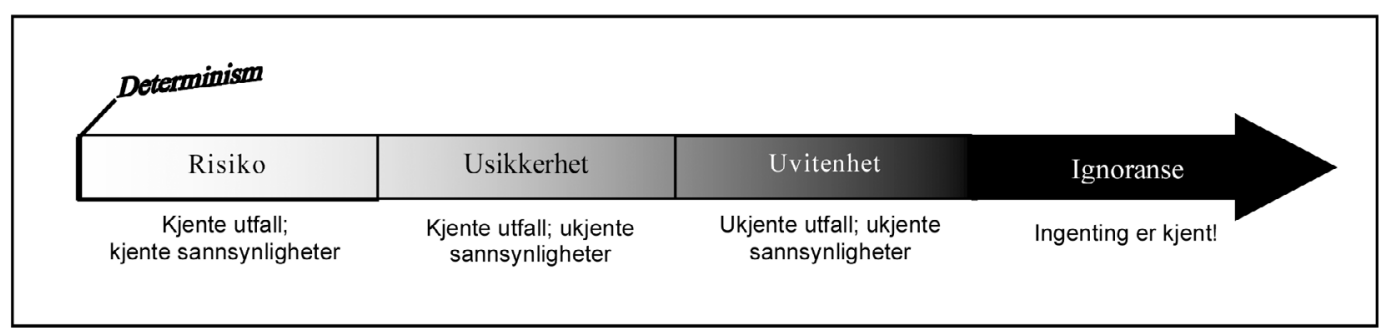

Figur 2 Grader av vitenskapelig usikkerhet (fra Walker et al., 2003)

Risiko er et begrep fra beslutningsteori som baserer seg på sannsynlighetsteori. Risiko beregnes ved å multiplisere konsekvensen av et utfall med sannsynligheten for at utfallet skal finne sted. En risikoanalyse innebærer at man veier nytte versus kostnader, noe som impliserer at alle konsekvensene samt sannsynligheten for at konsekvensene skal forekomme, er kjent. Usikkerhet oppstår når en kjenner mulige konsekvenser av en handling, men ikke kan beregne sannsynligheten for at de skal inntreffe. Uvitenhet inne- 
bærer at en verken kjenner konsekvensen av et utfall eller sannsynligheten for at utfallet skal finne sted, mens ignoranse vil si at fullstendige uventede konsekvenser kan oppstå, i og med at vi ikke engang vet hva vi ikke vet (Wynne 1992).

Det er som regel to kilder til vitenskapelig usikkerhet; begrenset kunnskap og naturlig variasjon i systemet som studeres. Begrenset kunnskap (epistemologisk usikkerhet) impliserer i de fleste tilfeller at mer forskning vil føre til at usikkerheten reduseres. Usikkerheten har dermed sin opprinnelse i vår manglende forståelse; for eksempel mangel på observasjoner eller målinger, at det finnes motstridende resultater, eller at det finnes forhold som ennå ikke er studert eller observert. Opprinnelsen til epistemologisk usikkerhet er ofte liten erfaring med teknologien.

Usikkerhet som derimot skyldes naturlig variabilitet og kompleksitet i systemet (ontologisk usikkerhet) vil ikke nødvendigvis reduseres gjennom mer forskning. Ontologisk usikkerhet forstås som en iboende egenskap ved systemet eller fenomenet som studeres (Walker et al. 2003). En anerkjennelse av dette innebærer en aksept av at usikkerhet knyttet til vår forståelse av et system kan øke som et resultat av mer forskning, da komplekse systemer kjennetegnes ved uvitenhet og ignoranse.

\section{Forskningens tradisjonelle håndtering av usikkerhet}

Den vitenskapelige metode baserer seg på hypotesetesting. I korthet innebærer dette at forskere fremsetter to hypoteser; $\mathrm{H}_{0}$ representerer den rådende vitenskapelige teori på et område, mens $\mathrm{H}_{1}$ representerer en alternativ teori. Analyse av innsamlet data, for eksempel fra eksperimenter eller observasjoner, samt valg av forkastningsområde avgjør hvilken hypotese som aksepteres. Hvis dataene ligger utenom forkastningsområdet, aksepteres $\mathrm{H}_{0}$, hvis dataene ligger innen forkastningsområde, forkastes $\mathrm{H}_{0}$, og en alternativ hypotese, $\mathrm{H}_{1}$, aksepteres som den rådende hypotesen.

Forkastningsområde defineres vanligvis før dataene samles inn, ut ifra sannsynligheten for type I og type II feil. Type I feil forekommer når $\mathrm{H}_{0}$ blir feilaktig forkastet og videre at $\mathrm{H}_{1}$ blir feilaktig akseptert som den rådende hypotesen. Type II feil begås når $\mathrm{H}_{0}$ feilaktig ikke blir forkastet og feilaktig akseptert som den rådende hypotesen. Standardmetoder i statistikk innebærer at en gjør mer for å unngå type I feil enn type II feil, da det betraktes som uheldig å påstå feilaktig at det er en effekt (uønsket helse- eller miljøeffekt), enn å overse en effekt (se tabell 1). Det må normalt foreligge sterke data for å kunne påstå at det er en effekt. 
Tabell 1 Type I og type II feil i økologiske studier. Null hypotese $H_{0}=$ Det er ingen skadelige effekter

\begin{tabular}{|l|l|l|}
\hline \multicolumn{1}{|c|}{ I naturen } & $\mathrm{H}_{0}$ er sann & $\mathrm{H}_{0}$ er usann \\
\hline $\begin{array}{l}\text { Undersøkelsen viser } \\
\text { ingen skadelige } \\
\text { effekter }\end{array}$ & Korrekt & $\begin{array}{l}\text { Type-II feil } \\
\text { Falsk negativ }\end{array}$ \\
\hline $\begin{array}{l}\text { Undersøkelsen viser } \\
\text { at det er skadelige } \\
\text { effekter }\end{array}$ & $\begin{array}{l}\text { Type-I feil } \\
\text { Falsk positiv }\end{array}$ & Korrekt \\
\hline
\end{tabular}

I miljø- og helsespørsmål involverer en aksept av en rådende $\mathrm{H}_{0}$ hypotese at et produkt ikke har noen uønsket effekt og at bevisbyrden flyttes til myndigheter og samfunn for å finne dokumentasjon som kan motbevise dette (Lemons et al. 1997). Valg av $\mathrm{H}_{0}$ blir dermed et verdivalg. På grunn av manglende symmetri mellom $\mathrm{H}_{0}$ og $\mathrm{H}_{1}$ blir relevansen av usikkerhet $\mathrm{i}$ denne sammenheng et etisk stridspunkt. Det har derfor blitt foreslått at forskere som arbeider med å utvikle og teste ny teknologi, skal prøve å minimalisere type II feil. Et slikt skifte av fokus har dessverre også sine ulemper, da det innebærer en risiko for å identifisere et trygt produkt eller prosess som farlig. Valget mellom å unngå type II feil (minimalisere risiko) eller type I feil (maksimere nytte) blir dermed både et etisk og et politisk valg.

Dette innebærer at forskeren bør vurdere det empiriske grunnlaget og alvorligheten av å akseptere en falsk hypotese eller forkaste en sann hypotese i beslutningen om å akseptere en vitenskapelig hypotese (eller ikke). I denne sammenheng blir analyse av forkastningsområde og den statistiske styrke relevant. Styrke henviser til sannsynligheten for å forkaste $\mathrm{H}_{0}$, det vil si påvise en effekt hvis den eksisterer. Styrkeanalyser er også verdifulle i planlegging av forsøk, fordi de gir indikasjoner på antall prøver og lengden på prosjektet. Styrkevurderinger er ofte utelatt i risikovurderinger, og det kan føre til en falsk trygghetsfølelse i forhold til studier som ikke finner noen skadelig effekt (Andow 2003). For å bøte på den manglende symmetrien mellom type I og type II feil har flere land introdusert føre-var-prinsippet i miljølovgivningen.

Det viktigste spørsmålet i denne sammenhengen er imidlertid om det er hensiktsmessig å basere seg på hypotesetestingsteori når en skal vurdere mulige uønskede effekter på helse og miljø. Ifølge Poppers terminologi kan en hypotese bare bli forkastet hvis den har blitt testet under ulike forhold (1959). Beskrivelsen av mulige konsekvenser som kan forekomme ved bruk 
av DNA-vaksiner i oppdrettsnæring, viser at det akvatiske økosystemet er komplekst, og at skadevirkninger kan være knyttet til gjensidige reaksjoner mellom ulike elementer i systemet. Det sier seg selv at det blir umulig å teste alle relevante hypoteser, og det setter et spørsmålstegn ved anvendeligheten av enkle modeller og tradisjonell hypotesetesting. Funtowicz og Ravetz (1990) argumenterer for at det ikke er mulig å redusere usikkerhet i komplekse systemer, siden en reduksjon i usikkerhet, som for eksempel å se på utvalgte deler av systemet, gir økt uvitenhet og manglende kontroll over helheten. I og med at aksept av ignoranse og uvitenhet innebærer en erkjennelse av «å ikke vite hva en ikke vet» er sannsynligheten stor for at relevante spørsmål aldri blir stilt. Idealiseringen eller forenklingen, som gjerne gjøres i et forsøk på å minske usikkerheten, kan dermed bidra til å øke uvitenheten. Dette reiser kritiske spørsmål til hypotesetestingsbasert forskning og strenge krav til refleksjon over gyldigheten til dataene som fremsettes.

\section{Håndtering av vitenskapelig usikkerhet og beslutningstakning i komplekse systemer}

\section{Nytte-kostnad-analyser}

For å regulere de økologiske og helsemessige konsekvensene ved bruk av ny teknologi kreves det konsekvensutredninger. Disse skal kartlegge risiko for helse- og miljømessige skadevirkninger og andre følger av en eventuell godkjenning av bruk av teknologien. Et tradisjonelt og mye brukt verktøy i denne sammenheng er nytte-kostnad-analyser, hvor nytte og kostnader kartlegges og vurderes, og det alternativet som fører til mest mulig nytte i forhold til kostnadene, velges. Metoden baserer seg på at nytte og kostnader verdsettes i økonomiske termer. Det sier seg selv at denne metoden kommer til kort ved risikovurderinger som omhandler langtidseffekter ved introduksjon av ny teknologi i komplekse systemer. Analysen har klare begrensinger på grunn av den iboende uforutsigbarheten ved bruk av ny teknologi. Beskrivelsen av mulige implikasjoner ved bruk av DNA-vaksiner i oppdrettsnæring, viser at en rekke konsekvenser må vurderes. Flere av disse konsekvensene er ukjente og vil muligens først oppstå over tid, samtidig som at sannsynlighetene for at konsekvensene inntreffer, er vanskelige å kvantifisere. Dermed blir det relevant å spørre om nytte-kostnadanalyser er en egnet metode for denne typen situasjoner. Dette problemet er ikke begrenset til DNA-vaksiner, men har også blitt tatt opp i relasjon til bruk og utsetting av genmodifiserte (GM) planter. Meyer og kolleger (2005) viser for eksempel til det problematiske forholdet mellom fakta, vitenskapelig evaluering av sannsynlighet og konsekvens, vurdering av akseptabel kostnad versus nytte, og signifikans av usikkerhet. 
Et annet problem med nytte-kostnad-analyser er at det vanligvis er stor uenighet om hvordan kostnad og nytte skal kategoriseres og balanseres mot hverandre (Christiansen \& Sandøe 2000). For eksempel er det vanskelig å kvantifisere miljøkostnader. Rammer og rekkevidde for spørsmål og muligheter kan også påvirke vurderingen av nyttevirkninger. Videre vil hva som blir vurdert som uønskede konsekvenser, være avhengig av verdisynet hos og prioriteringer av de som er involvert i risikovurderingene og i de politiske beslutningene (Wynne 2001).

\section{Usikkerhetsrammeverk}

Det følger av dette at kompleksiteten i naturlige og sosiale systemer, samt utfordringene med å håndtere at ny teknologi kan gi uønskede effekter over tid, nødvendiggjør utviklingen av alternative verktøy for risikovurderinger som i større grad tar høyde for kvalitative aspekter ved usikkerhet og verdiers innflytelse på forskning og forvaltning.

Det har imidlertid vist seg vanskelig å håndtere kvalitative aspekter av usikkerhet i praksis. Få verktøy er foreløpig utviklet med dette for øye. W\&H usikkerhetsrammeverk, utviklet av Walker et al. (2003), er ett eksempel på et analyseverktøy som karakteriserer og systematiserer kvalitative aspekter av vitenskapelig usikkerhet. Analyseverktøyet er beregnet på usikkerhet knyttet til vitenskapelige modeller som brukes i risikovurderingsprosesser. Målsettingene er å stimulere til økt kommunikasjon mellom forskere og beslutningstakere, bedre kvaliteten på data som legges til grunn for risikovurdering og beslutningstakning, samt indikere hvilke områder som bør prioriteres for videre forskning. Vitenskapelig usikkerhet defineres av Walker et al. (2003) som alt avvik fra det uoppnåelige idealet om fullstendig kunnskap. Videre skiller rammeverket mellom tre dimensjoner av vitenskapelig usikkerhet: i) hvor usikkerheten befinner seg i systemet, ii) nivået av usikkerhet (se figur 2), og iii) usikkerhetens natur (epistemologisk eller ontologisk).

Vi brukte W\&H usikkerhetsanalyse for å karakterisere usikkerhet knyttet til bruk av DNA-vaksiner i oppdrettsnæring. Tolv norske forskere som utfører forskning på fiskevaksiner eller arbeider innen forvaltning, ble intervjuet. Forskerne arbeidet ved offentlige (seks informanter) eller private (to informanter) forskningsinstitusjoner eller som rådgivere i forvaltningsorgan (fire informanter). Intervjuet tok utgangspunkt i figur 1 som illustrerer potensielle konsekvenser ved bruk av DNA-vaksiner i oppdrettsnæring. Hensikten var å avdekke vitenskapelig usikkerhet relatert til de ulike dimensjonene i W\&H-rammeverket. Figuren vektla tre mulige scenarier i beskrivelsen av relevante risikoaspekter knyttet til bruk av DNA-vaksiner: i) immunrespons, ii) distribusjon, lagring og ekspresjon av det injiserte DNA-plasmidet og iii) utslipp i det akvatiske miljøet (se figur 1). 


\section{Forskeres og forvalteres vurdering av usikkerhet ved bruk av DNA-vaksiner i oppdrettsnæring}

Alle informantene uttrykte at figur 1 er en god illustrasjon på mulige konsekvenser ved bruk av DNA-vaksiner i oppdrettsnæring, men det ble påpekt at sikkerhetsaspekter vedrørende feilstikk, selvvaksinering eller utilsiktet søling av vaksine under vaksinering ikke var inkludert. En rekke potensielle konsekvenser ved bruk av DNA-vaksiner ble identifisert av informantene og oppsummeres i tabell 2.

Tabell 2 Potensielle positive og negative konsekvenser ved bruk av DNA-vaksiner i oppdrettsnoring relatert til de ulike scenariene i figur 1

\begin{tabular}{|c|c|c|}
\hline Scenarier & $\begin{array}{l}\text { Mulige positive } \\
\text { konsekvenser }\end{array}$ & Mulige negative konsekvenser \\
\hline $\begin{array}{l}\text { Immun- } \\
\text { respons }\end{array}$ & $\begin{array}{l}\text { - Generell stimule- } \\
\text { ring av fiskens } \\
\text { immunsystem } \\
\text { - Kryssbeskyttelse }\end{array}$ & $\begin{array}{l}\text { - Ødeleggelse eller skade på } \\
\text { celler, vev eller organer forårsa- } \\
\text { ket av den induserte betennel- } \\
\text { sesreaksjonen } \\
\text { - Autoimmune reaksjoner } \\
\text { - Allergier } \\
\text { - Toleranse } \\
\text { - Utvikling av nye sykdommer } \\
\text { eller økt sårbarhet overfor nye } \\
\text { sykdommer } \\
\text { - Andre patologiske endringer }\end{array}$ \\
\hline $\begin{array}{l}\text { Distribusjon/ } \\
\text { lagring/ } \\
\text { ekspresjon av } \\
\text { injisert } \\
\text { DNA-vaksine }\end{array}$ & $\begin{array}{l}\text { - Generell stimule- } \\
\text { ring av fiskens } \\
\text { immunsystem } \\
\text { - Kryssbeskyttelse } \\
\text { - Indusert immun- } \\
\text { respons i andre } \\
\text { organer enn ved } \\
\text { injeksjonsted }\end{array}$ & $\begin{array}{l}\text { - Fragmenter av vaksinen inte- } \\
\text { greres i fiskens genom (inklu- } \\
\text { dert kjønnsceller) } \\
\text { - Rekombinasjon } \\
\text { - Somatiske mutasjoner } \\
\text { - Autoimmunitet } \\
\text { - Fragmenter av vaksinen tas } \\
\text { opp av andre organismer }\end{array}$ \\
\hline Miljøutslipp & & $\begin{array}{l}\text { - Spredning av DNA-vaksine til } \\
\text { andre organismer } \\
\text { - Spredning av motstandsdyktig- } \\
\text { het mot antibiotika til bakterier } \\
\text { - Endret funksjonalitet hos orga- } \\
\text { nismer som tar opp DNA-vak- } \\
\text { sinen } \\
\text { - Opptak av DNA-vaksine hos } \\
\text { mennesker og dyr som spiser } \\
\text { vaksinert fisk }\end{array}$ \\
\hline
\end{tabular}


Alle informantene vektla at sannsynligheten for at en gitt konsekvens skal finne sted, er svært situasjonsavhengig og vil variere, blant annet ut ifra type og mengde DNA-vaksine som injiseres samt injeksjonssted. Informantene ble ikke bedt om å vurdere alvorligheten av eller sannsynligheten for at konsekvensene skulle finne sted. Likevel sa seks av informantene at de anså sannsynligheten for at de negative konsekvensene skulle inntreffe og føre til skadelig effekt på menneskers helse eller miljø, som svært liten. Basert på dette, argumenterte enkelte for at det ikke er noen grunn til å stille strengere krav til risikovurdering av DNA-vaksiner enn de krav som allerede stilles til konvensjonelle vaksiner i bruk i dag.

Informantene nevnte ulike momenter da de ble bedt om å identifisere lokaliteten av vitenskapelig usikkerhet i figur 1 . Usikkerhet knyttet til autoimmunitet og opptak av DNA-vaksine blant mikroorganismer i det akvatiske miljøet, ble hyppigst nevnt, men totalt ble alle scenariene i figuren beskrevet som usikre med hensyn til mulige konsekvenser de kan medføre.

Nivået av usikkerhet for figuren generelt ble beskrevet som enten; «vi kjenner bredden av mulige parametere og årsaks-virkning-forhold og kan rangere dem basert på sannsynlighet» og «vi kjenner de fleste parametere, men kan ikke rangere dem basert på sannsynlighet». Majoriteten av informantene karakteriserte kilden av usikkerhet som epistemologisk og forventet at mer forskning kan redusere det meste av usikkerheten, selv om ontologisk usikkerhet også ble nevnt, spesielt i tilknytning til usikkerhet forbundet med utslipp til miljøet.

Studien viser at informantene var åpne for og oppmerksomme på at DNA-vaksinasjon representerer usikkerhet på en rekke områder. Samtidig viser studien at informantene hadde stor tillit til vitenskapen og dens evne til å redusere usikkerhet knyttet til DNA-vaksinasjon. Vi kunne ikke påvise noen sammenheng mellom informantenes arbeidssituasjon eller finansiering av forskningen og deres vurderinger av mulige konsekvenser og usikkerhet. Likevel mener vi at studien er med på understreke nødvendigheten av å inkludere flere forskere som rådgivere i en beslutningstakningsprosess. Informantene identifiserte ulike aspekter som usikre, vektla alvorligheten av dette noe forskjellig, og ga dermed totalt sett en mer helhetlig beskrivelse av hvilke forhold som bør inkluderes i en risikovurdering.

En av våre erfaringer med å gjennomføre en slik usikkerhetsanalyse er imidlertid at man må være forsiktig med å trekke for klare konklusjoner basert på analysen; det kan føre til et overforenklet bilde av den vitenskapelige usikkerheten. Vårt inntrykk er at informantene hadde begrenset erfaring med å uttrykke usikkerhet av kvalitativ karakter. Flere av informantene virket ukjent med begrepsbruken, og uttrykte selv at de manglet erfaring med å sette sitt eget arbeid inn i et helhetlig system, som illustrert i figur 1, samt å beskrive usikkerhet som går utover tradisjonelle statistiske termer. Til tross for dette mener vi at analysen representerer et viktig første skritt for 
å synliggjøre at det eksisterer usikkerhet på et dypere, kvalitativt nivå, samtidig som den gir forskere trening i og mulighet for å kommunisere vitenskapelig usikkerhet.

\section{Forskeransvar og kommunikasjon av vitenskapelig usikkerhet}

Vitenskapsetikk kan beskrives som forsøket på å beskrive, analysere og forstå den ideologi som brukes, og har vært brukt for å styre og legitimere vitenskapelig virksomhet (Hovedkomiteen for norsk forskning 1981). Etiske retningslinjer for forskning har tradisjonelt fungert som et eksternt normativt system for å beskytte individer og samfunnet (f.eks. informert samtykke, taushetsplikt) og et internt normativt system som setter standard for forskerne (f.eks. profesjonsetikk; ærlighet, redelighet og kompetent sannhetssøken). Merton (1973) var en av de første til å fremsette normer som må oppfylles for at vitenskapen skal realisere sine målsettinger for økt kunnskap og definerte universalisme, uegennytte, deling av kunnskap og en systematisk kritisk holdning som fire ethos for vitenskapen. Forskningsresultatene ble forutsatt å være gode i seg selv, og fokuset for vitenskapsetikken var de moralske kvalitetene ved forskerens handlinger, samt forskerens rettigheter, som akademisk frihet og autonomi (Hovedkomiteen for norsk forskning 1981).

Flere forhold taler for at det er behov for å utvikle etiske retningslinjer for forskning som omhandler andre områder enn de som tradisjonelt er ansett som relevante. Det rettes stadig mer oppmerksomhet mot forholdet mellom vitenskap, teknologi og samfunn. Rapporten Late lessons from early warnings (Harremoës et al. 2001) beskriver flere hendelser hvor bruk av ny teknologi har resultert i uventede alvorlige konsekvenser for menneskers helse og miljøet, problemer som ofte er av globale dimensjoner. En annen utfordring er at det i dag knyttes stadig sterkere bånd mellom økonomiske interesser og forskning og teknologiutvikling. Videre hviler politiske avgjørelser i økende grad helt eller delvis på forskningsresultater, siden forskere på grunn av sin ekspertkunnskap blir brukt som rådgivere ovenfor myndigheter som skal forvalte naturen og teknologien (Walker et al. 2003). Både vitenskapens og teknologiens betydning for samfunnsutvikling og økonomi, samt forskernes nye roller og ansvarsområder, er forhold som øker behovet for utvidede etiske retningslinjer for forskning.

Den nasjonale forskningsetiske komiteen for naturvitenskap og teknologi (NENT) har nylig utviklet nye retningslinjer. Dette er de første i sitt slag som omhandler naturvitenskapelig forskning i Norge. Her forsøker de å inkludere forhold som er av relevans for dagens forskning og forskere. Blant 
annet blir det fremhevet at forskere må reflektere over grensene for egen kunnskap og over usikkerhet i egne funn og resultater (NENT 2007):

Forskeren skal få klart frem hvilken grad av sikkerhet og presisjon forskningsresultatene kjennetegnes av. Spesielt skal forskeren være nøye med å klargjøre funnenes relative sikkerhets- og gyldighetsområde, og forskeren skal bestrebe seg på å påpeke eventuelle risiko- og usikkerhetsmomenter som kan ha betydning for eventuelle anvendelser av forskningsfunnene [...] Det er del av forskerens etiske ansvar og streben etter objektivitet å formidle et klart bilde av den relative sikkerheten og gyldigheten av kunnskapen. Der hvor det er mulig, bør forskere også benytte seg av egnete metoder for å fremstille usikkerhet i forskningen.

Dette er i tråd med Fjelland (1999), som diskuterer usikkerhetens plass i vitenskapen og argumenterer for at et første skritt $\mathrm{i}$ anerkjennelsen av vitenskapelig usikkerhet er at forskere kommuniserer denne usikkerheten. I tillegg oppfordrer NENT til at en skal bruke egnede metoder for å fremstille usikkerhet i forskning, hvor W\&H usikkerhetsanalyse kan være et mulig verktøy. NENT (2007) fremhever også at redelighet, sannferdighet og etterrettelighet er grunnleggende forskningsetiske krav som ved siden av anerkjennelse av usikkerhet innebærer åpenhet om verdier og interesser som har påvirket utforming og analyse av studien eller forskningsprosjektet.

\section{Verdivalg og usikkerhet}

Vurdering av hva som er et alvorlig miljøproblem, fornuftige tiltak og hvordan man bør forske på dem, er avhengig av verdisyn og etiske preferanser. Verdispørsmål relatert til bruk av ny teknologi er relevant både for kunnskapsproduksjon, forskning og teknologiutvikling. Verdier har også innflytelse på risikovurderingsprosesser og for beslutningene som blir tatt om bruk av ny teknologi.

\section{Verdier, usikkerhet og kunnskapsproduksjon}

Verdier er involvert i kunnskapsproduksjonen ved at de påvirker problemdefinisjon, hypotesedannelse, eksperimentdesign og datatolkning. Det er også avgjørende hvilken sammenheng studiene har blitt utført i; om det er grunnforskning, risikoassosiert forskning eller oppdragsforskning. En vitenskapelig tilnærming til et fenomen eller et problem innebærer at det gjøres valg i forhold til statistiske faktorer, samt hvilke modeller og parametere som skal brukes. Aspekter som vurderes som uvesentlige og usannsynlige, blir dermed utelatt. Disse valgene vil være avhengige av forskerens akademiske bakgrunn og arbeidssituasjon, finansiering, preferanser, verdisyn og ideologiske oppfatninger (Krayer von Krauss $2004 \&$ 2005). Faren er 
for eksempel at man innen utvikling og sikkerhetstesting av bioteknologiske produkter, som DNA-vaksiner, i for stor grad vektlegger spesifikk, sikker kunnskap (slik molekylærbiologien tilstreber) i motsetning til mer uspesifikk, generelle innsikter (som økologien kan bibringe). På denne måten risikerer man at verdivalget mellom relativt sikker nytte og relativt hypotetisk og usikker skade ikke blir avdekket eller fremstår som tydelig nok.

Uenighet blant forskere skyldes som regel at spørsmålene involverer mange store usikkerhetsmomenter, og at fremgangsmåter blir partielt fokusert på utvalgte aspekter, og det åpner derfor opp for fortolkninger. Ved siden av disiplinær bakgrunn påvirkes uenighet i forskersamfunnet av ideologiske og verdirelaterte aspekter. Hvordan en ser på et mulig problem, er avhengig av hvordan det kan ha innvirkning på for eksempel forbrukerinteresser, konsekvenser for nærmiljøet, økonomisk utvikling, bærekraft, innovasjons- og patentprosesser og hvor mye vekt en legger på disse ulike aspektene.

Som nevnt gir ikke vår DNA-vaksinestudie noe grunnlag for å hevde at forskernes og forvalternes vurderinger var avhengige av deres fagdisiplin eller nåværende arbeidssituasjon, men det illustrerer likevel betydningen av å involvere flere forskere med ulik bakgrunn som rådgivere i beslutningstakningsprosesser, slik at bredden av perspektiver og meninger i størst mulig grad blir belyst.

Kritikk og diskusjon er viktig i all naturvitenskapelig prosedyre. Kritikk er med på øke refleksjon over metodevalg og forbedre datainnsamling, og det kan lede til nye ideer for videre forskning. I debatten om bruk av genmodifiserte planter er det derimot mange forskere som argumenterer for at det finnes ett korrekt svar, men at interesser kommer i veien for denne sannheten (Meyer \& Sandø 2001). De legitimerer sitt standpunkt ut ifra ulike perspektiver, krediterer eget og samarbeidende partneres arbeid og sverter andres arbeid. Fra et slikt standpunkt bidrar uenighet til usikkerhet, og mer forskning vil ikke redusere usikkerheten, da det er høyst usannsynlig at konsensus vil kunne oppnås blant de stridende parter. Ifølge Latour (1987) er konkurrerende kunnskapsargumenter en karakteristikk av vitenskap og innebærer at de ulike argumentene blir fremmet gjennom ulike nettverk, og dessuten at det sterkeste nettverket får det viktigste kunnskapsargument, mens minoritetsopinionen strever med å overleve.

Sarewitz (2004) hevder at vitenskapelig uenighet om komplekse miljøproblemer er karakterisert av «for mye objektivitet». Det fører til at vitenskapelig usikkerhet kan forstås på ulike måter. Konkurrerende kunnskapsargumenter oppstår i beskrivelsen av problemet eller fenomenet og i forhold til hvilke beslutninger som skal fattes. En utfordring blir da hvordan en skal forholde seg til usikkerhet og den uenigheten den fører med seg. Dupré (2001) og Funtowicz og Ravetz (1990) hevder at for å reise kvaliteten på den 
vitenskapelige diskusjonen bør en gå vekk fra det strenge skillet mellom fakta og verdier som er grunnlaget for tradisjonell vitenskap.

\section{Verdier, usikkerhet og risikovurderinger}

Verdier påvirker risikovurderinger og beslutninger ved å sette rammer for hvilke aspekter som anses som relevante, hvordan usikkerhet vektlegges, i hvilken grad motstridende ekspertuttalelser inkluderes, samt valg av hvilke eksperter og eventuelt legfolk som skal involveres i vurderingen. Verdier påvirker også vurderingen av kunnskapsgrunnlaget og en eventuell anerkjennelse av mangel på relevante studier, for eksempel om fravær av resultater blir tolket som at det ikke finnes bevis på skadelige effekter. Ett eksempel er hvordan usikkerhet knyttet til muligheten for integrering av DNAvaksine i fiskens genom, har fått ulike betydninger for europeiske myndigheter. Mens britiske myndigheter ikke anser DNA-vaksinert fisk som genmodifisert, har norske myndigheter gjort et verdivalg: De hevder at så lenge en ikke kan bevise at DNA-vaksinen ikke kan detekteres i fisken, så bør fisken merkes som en GMO (Direktoratet for naturforvaltning 2001; Foss \& Rogne 2003). Det viser at vitenskapelig usikkerhet om uønskede effekter har både etiske og politiske implikasjoner. Verdier påvirker dermed dannelse av normer for prosedyrer når det gjelder myndigheters arbeid med hensyn til implementering av lover, politiske prosesser ved oppnevning av faglige utvalg og beslutningsorganer, og prioriteringer av midler til forskning og innovasjon (inkludert produktutvikling vs. risikoassosiert forskning). Føre-var-prinsippet har de siste årene blitt integrert i mange lands miljølovgivning. Mange hevder at føre-var-prinsippet skal brukes etter at det er gjort en risikoanalyse eller nytte-kostnad-analyse. På denne måten fungerer prinsippet kun som et politisk eller administrativt prinsipp som ikke har noe med etikk eller forskning å gjøre (Fairbrother \& Bennet 1999). Andre hevder at føre-var-prinsippet er et viktig ledd i en risikoanalyse eller en nytte-kostnad-analyse fordi det involverer et bredt vitenskapelig perspektiv på mulige risikomomenter (se f.eks. Foster et al. 2000; Myhr \& Traavik 2003). Forskjellen mellom en nytte-kostnad-analyse og bruk av føre-var-prinsippet er relatert til bevisbyrde, vektlegging av vitenskapelige bevis og usikkerhet.

\section{Fore-var-prinsippet}

Føre-var-prinsippet er et normativt prinsipp i en rekke internasjonale traktater og avtaler innen miljø og forvaltning av naturressurser, samt i ulike nasjonale lovtekster som for eksempel den norske genteknologiloven. Den 
klassiske formuleringen av prinsippet finnes i Rio-deklarasjonen (1992), artikkel 15:

Der hvor det foreligger trussel om alvorlige eller uopprettelig skade, skal ikke mangel på fullstendig vitenskapelig visshet kunne brukes som begrunnelse for å utsette kostnadseffektive tiltak for å hindre miljøforringelse.

Denne versjonen av prinsippet kan ses på som passiv. Den viser til hvilke argumenter som taler for å bruke prinsippet, men foreskriver ikke handling (Sandin 1999). Det finnes mange andre formuleringer av prinsippet Wingspread-erklæringen er en mer aktiv versjon: «Når det er fare for skade på menneskers helse eller miljøet, skal føre-var-baserte tiltak iversettes selv om klare årsaks-virkning-mekanismer ikke er fullstendig bevist» (vår oversettelse) (Raffensperger \& Tickner 1999: 345-355).

Prinsippet, valg av sterke eller svake formuleringer, dets bruk og konsekvenser er et omstridt tema (Gardiner 2006; Morris 2002; Kriebel et al. 2001). Likevel står fire elementer sentralt: i) implementering av preventive tiltak for å hindre skade på menneske og miljø, selv når det er usikkert om mulige skadelige konsekvenser vil forekomme, ii) skifte i bevisføring, slik at den som utvikler nye produkter og teknologi, må bevise trygg anvendelse, iii) krav om å utforske alternativer til mulige skadelige handlinger, og iv) økt folkelig deltakelse i beslutningstakningsprosesser (Kriebel et al. 2001). Dette synliggjør den viktige rollen prinsippet spiller i prosessen med å anerkjenne vitenskapelig usikkerhet, både innen forskning og forvaltning.

I forhold til forskning innebærer føre-var-prinsippet først og fremst at forskere prøver å: i) identifisere usikkerhet og fareelementer, ii) initiere risikoassosiert forskning, og iii) kommunisere usikkerhet til andre forskere og beslutningsmyndigheter. Kriebel et al. (2001) diskuterer hvordan forskningsmetoder bør utvikles for å imøtekomme føre-var-prinsippet og nevner spesielt behovet for en helhetlig tilnærming til problemet, gjerne i form av tverrfaglige forskergrupper og bruk av modeller som i større grad representerer komplekse systemer. På denne måten begrenses ikke hypoteseformuleringen til et forsøk på å avdekke enkle årsaks-virking-forhold som har liten relevans for en virkelighetsnær beskrivelse av systemet. Videre påpeker de behovet for å utvikle nye statistiske metoder som gir rom for formidling av kvalitative aspekter ved vitenskapelig usikkerhet. Samtidig understreker de styrkene ved tradisjonelle forskningsmetoder og understreker at føre-var-baserte forskningsmetoder ikke bør erstatte disse metodene, men introduseres som et supplement, slik at de to tilnærmingene kan utfylle hverandre og bidra til kunnskapsutvikling av best mulig kvalitet.

Foster et al. (2000) understreker at det er viktig å følge opp tiltak som initieres under føre-var-prinsippet med kontinuerlig evaluering av funn både i form av overvåkning og risikoassosiert forskning. Forskning som kan gi holdepunkter for forhåndsvurderinger av risiko, involverer en helt annen 
type forskning enn den som tar utgangspunkt i antakelser om sikkerhet. Innovasjonsdrevet forskning drives fremover av ideer, hypoteser og teorier, samt en sterk tro på at produktet eller prosessen har nyttevirkninger. Det er vanskelig for slike miljø å vise like stor innovasjonsevne ved undersøkelse av potensielle skadevirkninger. Flere av forskerne som deltok i vår usikkerhetsanalyse, uttrykte for eksempel at det var uvant for dem å sette DNAvaksinasjon inn $i$ et helhetlig system som inkluderte andre aspekter enn forventet immunrespons etter vaksinasjon. Forskning som har til hensikt å undersøke risiko, bør derfor utføres av forskningsmiljøer som er uavhengige av økonomiske og politiske interesser. Identifisering av mulige risikomomenter på et tidlig tidspunkt i prosessen og gjennom samarbeid mellom uavhengige forskningsmiljøer og laboratorier, vil kunne bidra til en tryggere utvikling samtidig som at produsentene sparer ressurser.

Beslutningstakere bør vente med å ta i bruk ny teknologi, til en har innhentet mer kunnskap om risikomomentenes sannsynlighet og tilhørende konsekvenser, dersom anvendelse av teknologien kan føre til alvorlige eller irreversible skade på helse og miljø. Vi har tidligere diskutert at en føre-varholdning impliserer at en må godta større usikkerhet, dersom en ønsker å minimere type II feil. Dette innebærer at beslutninger tas før en har klare dokumenterte skader som følge av bruk av en gitt teknologi. Enkelte av informantene som deltok i vår studie mente at det ikke er nødvendig å stille strengere krav til risikovurderinger av DNA-vaksiner enn de krav som stilles konvensjonelle vaksiner, og argumenterte for at vaksinering foreløpig ikke har ført til uakseptable skadelige konsekvenser. Vi tolker dette som manglende vilje til å akseptere en føre-var-basert tilnærming til ny teknologi som kan representere unike egenskaper og dermed unike risikoer.

Det er ingen tvil om at anvendelsen av føre-var-prinsippet er vanskelig å kontroversielt. Noen ser på føre-var-prinsippet som et hinder for teknologibruk og handel mens andre ser på det som nødvendig for å hindre skade på miljø og helse. Hvordan en skal bruke det, er også komplisert. Ulike ekspertutvalg har for eksempel behandlet spørsmål knyttet til risiko og usikkerhet forskjellig. Matthias Kaiser (2003) i NENT har sammenliknet hvordan enkelte ekspertgrupper (Walløe-utvalget, NOU 2000:29 om genmodifisert mat versus Gjørv-utvalget, NOU 2001:18 om xenotransplantasjon) la vekt på usikkerhet. Walløe-utvalget unntatt et medlem ønsket sikre bevis for usikkerhet før føre-var-prinsippet kunne komme til anvendelse, mens Gjørv-utvalget vektla usikkerhet og mente at føre-var-prinsippet burde komme til anvendelse for å utsette bruk av xenotransplantasjon inntil mer kunnskap var innhentet. Det er derfor ikke tvil om at videre diskusjon og utredning er nødvendig for at føre-var-prinsippet skal bli anvendt i etiske og politiske saker på et god måte. 


\section{Interdisiplinære tilnærminger til usikkerhet}

Vi har flere ganger nevnt at bruk av ny teknologi innebærer at det er vanskelig å forutse konsekvenser eller få oversikt over alle mulige skadevirkninger og risikofaktorer dersom den tas i bruk. Slik vi ser det, ligger de aller største forskningsmessige utfordringene i å identifisere gode metoder og etablere modellsystemer som har relevans til virkelighetens kompleksitet. Interdisiplinæritet er en mulig tilnærming. Interdisiplinære aktiviteter kan være både flerfaglig og tverrfaglig, og begge tilnærmingene kan forsvares ut ifra både metodologiske, epistemologiske og ontologiske argumenter. Flerfaglighet vil gi en bredere epistemologisk forståelse av et fenomen eller et problem ved at de ulike disiplinene tar ansvar for ulike deler av prosjektet og bidrar med sine metoder og kunnskaper for løsning av sin del. Tverrfaglighet inkluderer en flerfaglig tilnærming hvor de ulike disipliners kunnskapssystem blir sammenlignet, og fører til at en utforsker alternative forståelser og løsninger. En slik sammenligning bør inkludere en samordning av ulike typer nivå av kunnskap. Således vil den kunnskapen som produseres, være en ontologisk annerledes kunnskap enn den som hver disiplin produserer for seg selv.

En tverrfaglig tilnærming vil hjelpe til med å

- forstå og fremme refleksjon om nye og ukjente perspektiver,

- utforske alternative problemdefinisjoner og indikatorer som bli brukt til å vurdere nytte og mulige uønskede effekter,

- fungere som en kilde av kunnskap, data og informasjon om både fakta og usikkerhet som kan være relevante for vurdering og forvaltning av risiko,

- evaluere og vurdere de antakelsene og metodene som brukes i risiko assosistert forskning samt eventuelle resultater. Med mer diversitet i tilnærmingen til problemet eller fenomenet vil mer data bli innhentet, og flere responser vil være tilgjengelig i tilfelle uventede hendelser skulle oppstå.

Interdisiplinær forskning er utfordrende og krever at alle er interessert og villig til å komme de ulike disiplinene i møte. En annen utfordring for interdisiplinære tilnærminger er hvordan en skal unngå konkurrerende kunnskapsargumenter, fremfor å se og akseptere disse argumentene som komplementære, samt å bidra til at de impliserte partene kan kommunisere de verdier, interesser og antakelser som utgjør rammene for deres tilnærming til usikkerhet.

En av målsettingene med W\&H usikkerhetsanalyse er å stimulere til økt kommunikasjon mellom forskere og forvaltere, bedre kvaliteten på data som legges til grunn for risikovurdering, og indikere hvilke områder som bør prioriteres for videre forskning. Studien vår synliggjorde nettopp at 
ulike forskere og forvaltere vektlegger mulige konsekvenser og sannsynligheten av disse noe forskjellig. Vår erfaring tilsier at W\&H usikkerhetsanalyse kan være et nyttig verktøy for å identifisere og systematisere ulike forståelser av vitenskapelig usikkerhet ved oppstart av tverrfaglige prosjekter.

I tillegg til at tverrfaglighet reiser store metodiske utfordringer, er en annen utfordring å få forskere til å anerkjenne og involvere relevant legkunnskap. Slik kunnskap kan være relatert til lokale forhold og erfaringer som kan være med på å bestemme hvilke antakelser, data, metoder og modeller som er relevante. Ved bruk av DNA-vaksiner i oppdrettsnæring er for eksempel havbruksnæringen, fiskeoppdrettere, konsumenter og miljøvernorganisasjoner relevante interesseparter. Ved å involvere legfolk kan også den samfunnsmessige sammenhengen som teknologien skal brukes $\mathrm{i}$, bli inkludert og belyst på en bedre måte.

\section{Konklusjon}

Basert på en usikkerhetsanalyse av vitenskapelig usikkerhet knyttet til bruk av DNA-vaksiner i oppdrettsnæringen, har vi forsøkt å illustrere viktigheten av, men også de praktiske utfordringene forbundet med, å inkludere kvalitative aspekter av vitenskapelig usikkerhet i forskning og forvaltning.

Usikkerhetsanalysen ble utført blant tolv ledende norske forskere og forvaltere som arbeider innen fiskevaksineutvikling eller i forvaltningsorgan. Analysen viste at introduksjon av DNA-vaksiner i oppdrettsnæring kan resultere i en rekke utilsiktede konsekvenser, at det er knyttet stor vitenskapelig usikkerhet til hvorvidt disse konsekvensene vil inntreffe, og om de er en trussel mot helse og miljø. Usikkerheten ble i all hovedsak ansett som epistemologisk, da informantene forventet at mer forskning og utvikling av nye forskningsverktøy vil kunne redusere usikkerheten tilstrekkelig. Studien viste at informantene manglet erfaring i å uttrykke usikkerhet i kvalitative termer, samt å se sitt eget forskningsarbeid i et helhetlig perspektiv. I tillegg til å identifisere vitenskapelig usikkerhet, representerer usikkerhetsanalysen dermed en anledning for informantene til å reflektere over og kommunisere vitenskapelig usikkerhet.

En tilfredsstillende håndtering av vitenskapelig usikkerhet i forskning og forvaltning innebærer først og fremst at risikovurderinger inkluderer konsekvenser på både kort og lang sikt. Risikoassosiert forskning som innebærer at forskere utfører studier som går over lang tid og har en bred innfallsvinkel til problemet, ved at de stiller åpne problemformuleringer og aksepter alternative forklaringsmodeller, vil kunne gi viktig kunnskap i denne sammenheng. En helhetsvurdering av tilgjengelig informasjon kan best oppnås ved å inkludere tverrfaglig ekspertise i identifikasjon og vurdering av risiko og usikkerhet. Samtidig er det viktig å erkjenne at forskeres 
vurdering påvirkes av deres verdier og interesser. Dette er en av flere grunner til at legfolk, og den kunnskapen de representerer, bør inkluderes i beslutningstakningsprosesser.

Det er ingen tvil om at det er krevende å inkludere og håndtere vitenskapelig usikkerhet på en tilstrekkelig måte i forskning og beslutningstakning. Samtidig vil konsekvensene kunne bli dramatiske dersom vi ikke prøver. Etikk handler om å gjøre rette valg. Disse valgene må bygge på kunnskapen vi har, men også på en åpenhet omkring verdiene som ligger til grunn for denne kunnskapen, samt hva vi faktisk ikke vet. En aksept av dette vil være et viktig skritt for å bedre forskningen og forvaltningens håndtering av vitenskapelig usikkerhet.

\section{Litteratur}

Andow, D. (2003) Negative and positive data, statistical power, and confidence intervals. Environmental Biosafety Research, 2, s. 75-80.

Bergh, Ø., Fjelldal, P. G., Hansen, T., Juell, J. E. \& Nerland, A. (2006) Dyrevelferdsmessige konsekvenser av vaksinasjon av fisk - effekter og bivirkninger. Fisken og Havet, 9, s. 1-43.

Christiansen, S. B. \& Sandøe, P. (2000) Bioethics: limits to the interferense with life. Animal Reproduction Science, 60-61, s. 15-29.

Chu, D., Strand, R. \& Fjelland, R. (2003) Theories of Complexity: Common Denominators of Complex Systems. Complexity, 8, s. 19-30.

Cilliers, P. (2005) Complexity, Deconstruction and Relativism. Theory, Culture of Society, 22, s. 255-267.

Dupré, J. (2001) Human nature and the limits of science. Oxford: Oxford University Press.

Fairbrother, A. \& Bennett, R. S. (1999) Ecological risk assessment and the precautionary principal. Human and Ecological Risk Assessment, 5, s. 943-950.

Fjelland, R. (1999) Vitenskap mellom sikkerhet og usikkerhet. Sarpsborg: Ad Notam Gyldendal.

Foss, G. S. \& Rogne, S. (2003) Gene medification or genetic modification? The devil is in the details. Nature Biotechnology, 21, s. 1280-1281.

Foster, K. R., Vecchia, P. \& Repacholi, M. H. (2000) Science and the precautionary principle. Science, 288, s. 979-981.

Funtowicz, S. O. \& Ravetz, J. R. (1990) Uncertainty and Quality in Science for Policy. Dordrecht: Kluwer.

Gardiner, S. M. (2006) A core precautionary principle. The Journal of Political Philosophy, 14, s. 33-60.

Harremoës, P., Gee, D., MacGarvin, M., Stirling, A., Keys, J., Wynne, B. \& Vaz, S. G. (red.) (2001) The precautionary principle in the 20th century. Late lessons from early warnings. London: Earthscan Publications Ltd. Lastet ned 25. august 2007 fra http://reports.eea.eu.int/environmental_issue_report_2001_22/ 
Heinemann, J. A. \& Roughan, P. D. (2000) New hypotheses on the material nature of horizontally transferred genes. Annals of the New York Academy of Science, 906, s. 169-186.

Hew, C. L. \& Flecher, G. L. (2002) The role of aquatic biotechnology in aquaculture. Aquaculture, 197, s. 191-204.

Hines, P. J. (2001) The dynamics of scientific controversies. Agbio Forum, 4, s. $186-$ 193.

Kaiser, M. (2003) Ethics, science and precaution: A view from Norway. In: Precaution, environmental science, and preventive public policy, red. J. Tickner, s. 3955. Washington D.C.: Island press.

Klinman, D. M., Yi, A. K., Beaucage S. L., Conover, J. \& Krieg, A. M. (1996) CpG motifs resent in bacterial DNA rapidly induce lymphocytes to secrete interleukin 6, interleukin 12, and interferon gamma. Proceedings of the National Academy of Sciences, 93, s. 2879-2883.

Krayer von Krauss, M. P., Casman, E. A. \& Small, M. J. (2004) Elicitation of Experts Judgements of Uncertainty in the Risk Assessment of Herbicide-Tolerant Oilseed Crops. Risk Analysis, 24 (6), s. 1515-1527.

Krayer von Krauss, M. P. (2005) Uncertainty in policy relevant sciences. PhD Thesis, Institute of Environment and Resources, Technical University of Denmark.

Kriebel, D., Tickner, J., Epstein. P., Lemons. J., Levins, R., Loecher, E. L., Quinn, M., Rudel, R., Schettler, T. \& Soto, M. (2001) The Precautionary Principle in environmental science. Environmental Health Perspectives, 109, s. 871-876.

Latour, B. (1987) Science in action. How to follow scientists and engineers through society. Cambridge: Harvard University Press.

Lemons, J., Shrader-Frechette, K. S. \& Cranor, C. (1997) The precautionary principle; Scientific uncertainty and type I and type II errors. Foundation of Science, 2, s. 207-236.

Leong, J. C. \& Fryer, J. L. (1993) Viral vaccines for aquaculture. Annual Review of Fish Diseases, 3, s. 225-240.

Lorenzen, N., Lorenzen, E., Einer-Jensen, K. \& LaPatra, S. E. (2002) Immunity induced shortly after DNA vaccination of rainbow trout against rhabdoviruses protects against heterologous virus but not against bacterial pathogens. Developmental \& Comparative Immunology, 26, s. 173-179.

Merton, R. K. (1973) The sociology of science: theoretical and empiricial investigation. Chicago: University of Chicago Press.

Meyer, G. \& Sandø, P. (2001) Dialogue on plant biotechnology. Danmark: The centre of bioethics and risk assessment.

Meyer, G., Folker, A. P., Jørgensen, R. B., Krayer von Krauss, M., Sandø, P. \& Tveit, G. (2005) The factualization of uncertainty: Risk, politics, and genetically modified crops - a case of rape. Agriculture and Human Values, 22, s. 235-242.

Mor, G., Yamshchikov, G., Sedegah, M., Takeno, M., Wang, R., Houghten, R. A., Hoffman, S. \& Klinman, D. M. (1996) Induction of neonatal tolerance by plasmid DNA vaccination of mice. The Journal of Clinical Investment, 98, s. 2700-2705.

Morris, J. (2002) The relationship between risk analysis and the precautionary principle. Toxicology, 181-182, s. 127-130.

Myhr, A. I. \& Traavik, T. (2003) The Precautionary Principle: Scientific uncertainty and omitted research in the context of GMO use and release. Journal of Agricultural and Environmental Ethics, 15, s. 73-86. 
Myhr, A. I. \& Dalmo, R. A. (2005) Introduction of genetic engineering in aquaculture; ecological and ethical implications for science and governance. Aquaculture, 250, s. 542-554.

Norge, Direktoratet for naturforvaltning (2001) Svar angående forespørsel om hvorvidt klinisk utprøving av DNA-vaksine på fisk faller inn under genteknologiloven. Ref. 2001/1556-EØ Ark. 371.0.

Norge, Hovedkomiteen for norsk forskning (1981) Forskning og etisk ansvar: en rapport fra utvalget for forskning og etikk, Oslo.

Norge, NENT (2007) Forskningsetiske retningslinjer for naturvitenskap og teknologisk forskning. Lastet ned 25. august 2007 fra http://www.etikom.no/retningslinjer/nent/pdf.

Norge, NOU 2000: 29 GMO-mat Helsemessige konsekvenser ved bruk av genmodifiserte næringsmidler og næringsmiddelingredienser. Innstilling fra et ekspertutvalg oppnevnt ved kongelig resolusjon 19. januar 2000. Avgitt til Sosial- og helsedepartementet 2. oktober 2000 Lastet ned 27. september 2007 fra http://www.regjeringen.no/nb/dep/hod/dok/NOUer/2000/NOU-2000 29.html?id=143253

Norge, NOU 2001: 18 Xenotransplantasjon Medisinsk bruk av levende celler, vev og organer fra dyr. Innstilling fra et utvalg oppnevnt ved kongelig resolusjon 3. desember 1999. Avgitt til Kirke-, utdannings- og forskningsdepartementet 20. juni 2001. Lastet ned 27. september 2007 fra http://www.regjeringen.no/nb/ $\mathrm{dep} / \mathrm{hod} / \mathrm{dok} / \mathrm{NOUer} / 2001 / \mathrm{NOU}-2001-18 . \mathrm{html}$ ?id=143 754

Norge, Statistiske sentral byrå (2007) Toppår for oppdrettslaks. Lastet ned 25. august $2007 \mathrm{fra} \mathrm{http://www.ssb.no/vis/emner/10/05/fiskeoppdrett/main.html}$

Novartis (2005) Nowartis media release July 19, 2005. Lastet ned 25. august 2007 fra http://www.novartis.com.

Popper, K. R. (1959) The logic of scientific discovery. New York: Basic books.

Prigogine, I. (1980) From being to becoming: time and complexity in the physical sciences. San Fransisco: W.H. Freeman.

Sandin, P. (1999) Dimensions of the Precautionary Principle. Human and Ecological Risk Assessment, 5 (5), s. 889-907.

Sarewitz, D. (2004) How science makes environmental controversies worse. Environmental Science \& Policy, 7, s. 385-403.

Stirling A. (2001) On science and precaution on risk in the management of technological risk. An ESTO Project Report Prepared for the European Commission JRC. Institute Prospective Technological Studies. Seville. Lastet ned 27. september $2007 \mathrm{fra} \mathrm{ftp} . j \mathrm{rc} . \mathrm{es} / \mathrm{pub} /$ EURdoc/eur19 056en.pdf.

Tonheim, T., Leirvik, J., Løvoll, M., Myhr, A. I., Bøgwald, J. \& Dalmo. R. A. (2007) Detection of supercoiled plasmid DNA and luciferase expression in Atlantic salmon (Salmo salar L.) 535 days after injection. Fish and Shellfish Immunology, 23 (4), s. 867-876.

Walker, W. E., Harremoeës, P., Rotmans, J., van der Sluijs, J. P., van Asselt, M. B. A., Janssen, P. \& Kraye von Krauss, M. P. (2003) Defining uncertainty; a conceptual basis for uncertainty management in model based decision support. Journal of Integrated Assessment, 4, s. 5-17.

Wynne, B. (1992) Uncertainty and environmental learning: reconciving science and policy in the preventive paradigm. Global Environmental Change, 2, s. 111127. 
Wynne, B. (2001) Creating public alienation: Expert cultures of risk and ethics on GMOs. Science as Culture, 10, s. 445-481. 